\title{
Okul Öncesi Dönemde Özel Yetenekli Bir Çocuk Yetiştirmek
}

\author{
SÜREYYA YÖRÜK
}

Özet

Okul yılları, özel yetenekli çocukların akademik, sosyal ve duygusal gelişim süreçlerinde çok önemli bir yer tutar. Ancak okul öncesi dönemdeki yaşantı da bir o kadar önemlidir. Özel yetenek tanısı alan çocukların okul öncesi dönemdeki gelişimlerinde en büyük pay da ebeveynlere aittir. Özel yetenekli bir çocuğa sahip olan veya çocuklarının özel yetenekli olduğunu düşünen ebeveynlerin zihinlerinde birçok soru vardır. Bu ebeveynlerin, özel yetenek tanısı almadan önceki, özel yetenek tanısı alma esnasındaki ve özel yetenek tanısı aldıktan sonraki süreçle alakalı bazı önemli soruların cevaplarını bilmeleri, bu süreci daha sağlıklı bir şekilde sürdürmeleri bakımından elzemdir. Bu çalışmada, ebeveynlerin özel yetenekli bir çocuk yetiştirirken dikkat etmeleri gereken önemli noktalar üzerinde durulmaktadır.

Anahtar Kelimeler: Özel yetenek, ebeveyn, erken çocukluk dönemi, çocuk gelişimi
Abstract
- ARASTIRMA MAKALESI-
SÜREYYA YÖRÜK, sureyya.yoruk@marmara.edu.tr Marmara Üniversitesi ORCID: https://orcid.org/0000-0001-8181-2614

School years play an important role in the academic, social and emotional development of gifted children. However, life in the preschool period is just as important. Parents has the biggest impact on the development of gifted children in preschool years. Parents who have a gifted child or think that their child is gifted have many questions in mind. In order to support their child during his or her development process in an appropriate way, it is essential for those parents 
to know the answers to some important questions about pre-identification, identification, and post-identification processes of giftedness. This article focused on certain crucial aspects that parents should consider while raising a gifted child.

Keywords: Giftedness, parents, early childhood, child development

\section{Giriş}

Birçok ebeveyn, doğumdan sonraki birkaç yıl içinde çocuklarını dikkatlice gözlemler ve gözlemlerini bir uzmanla paylaşarak çocuklarının özel yetenekli olup olmadığını öğrenmek ister. "Evet, çocuğunuz özel yetenekli." cevabını alana kadar geçen bu süreç, aslında işin kolay olan kısmıdır. Çünkü çocuklarının özel yetenekli olduğunu öğrenen birçok anne-baba, ne yapacağını tam olarak bilemez ve şu sorunun cevabını aramaya koyulur: Acaba şimdi ne yapmalıyım? Bu çalışmada, özel yetenekli bir çocuk sahibi olduğunu düşünen ve özel yetenekli bir çocuk sahibi olduğunu bilen ebeveynlerin, tanı almadan önceki, tanı alma esnasındaki ve tanı aldıktan sonraki süreçte cevaplarını aradıkları bazı önemli sorular, erken çocukluk dönemi dikkate alınarak incelenmiştir.

Daha fazla ilerlemeden önce, kavram karmaşasını engellemek için bir hususu belirtmek faydalı olacaktır. Çalışmaya konu olan çocukları tanımlamak için uzun yıllar boyunca ülkemizde kullanılan terim, "üstün zekâlı" terimiydi. Bu terimin IQ'ya (Intelligence Quotient) yaptığı vurgu ve sınırlayıcı etkisi nedeniyle Milli Eğitim Bakanlığı yaklaşık 8-10 yıldan beri bu terim yerine, ‘özel yetenekli’ teriminin kullanılmasını önermektedir. Takip eden bölümlerde, Milli Eğitim Bakanlığı'nın önerdiği terim kullanılmıştır.

\section{Özel Yetenekli Çocuk Kimdir?}

Bu soruya yüzyıl önce verilen cevap, "Bir IQ testinden ortalamanın en az iki standart sapma üstünde puan alan, yani IQ'su 130'dan büyük olan çocuktur.” şeklindeydi (Jolly, 2005). Özel yetenekli çocukların bir IQ testinden çok yüksek puan alması gerektiğine yönelik bu görüş, aileler ve alan dışında çalışma yürüten araştırmacılar tarafından hâlâ yaygın bir şekilde benimsense de yukarıdaki cevap, günümüz alan uzmanlarının neredeyse tamamı tarafindan eksik bir cevap olarak kabul ediliyor. Fakat bunun gerekçesi, özel yetenekli çocukların özelliklerinin değişmesi değildir. 2020/2 Bundan farklı olarak temel sebep, alan uzmanlarının özel yeteneğe ilişkin bakış açılarının daha geniş bir kitleyi kapsayacak şekilde değişmesidir (bkz. 
Gagné, 2004; Gardner, 1983; Marland, 1972; Renzulli, 1986; Sternberg, 2005). Mili Eğitim Bakanlığı'nın, özel yetenek terimini önermesinin sebeplerinden birinin bu değişim olduğu vurgulanmalıdır.

\section{Modern Bakış Açısına Göre Özel Yetenek}

Modern görüşe göre özel yetenekliler grubu, sadece yüksek IQ sahibi çocuklardan oluşmaz (bkz. Gagné, 2004; Gardner, 1983; Marland, 1972; MEB, 2018; Renzulli, 1986; Sternberg, 2005). Bu nedenle “Özel yetenekli çocuk kimdir?” sorusunu bugün sorduğumuzda verilen cevap, "Genel zihinsel yetenek (IQ), yaratıcı düşünme, sanat, liderlik, psikomotor ve akademik alanların en az birinde, yaşıtlarından daha yüksek başarı potansiyeline sahip olan veya başarı gösteren çocuktur." olarak karşımıza çıkmaktadır (Marland, 1972). Ancak özel yetenek bağlamında önemli olan husus, çocuğun var olan yüksek potansiyelini, yüksek bir performansa dönüştürebilmesidir.

Yukarıdaki tanımdan yola çıkarak şu çıkarımlar yapılabilir: Bazı özel yetenekli çocuklar yüksek IQ'ya sahiptirler; ancak çok yüksek IQ sahibi olmayan özel yetenekli çocuklar da vardır. Sanat alanlarında özel yetenekli olup da ortalama üstü bir IQ sahibi (IQ < 130) olan çocuklar buna örnek verilebilir. Ayrıca birçok özel yetenekli çocuğun, IQ ve akademik alanlar gibi birbirine yakın veya IQ, liderlik, sanat ve psikomotor gibi birbirinden farklı alanlarda aynı anda özel yetenekli olduğu görülse de tek bir alanda özel yetenekli olan çocuklar da vardır. Psikomotor alanlarda özel yetenekli ama diğer alanlarda ortalama veya ortalama üstü başarı gösteren çocuklar buna örnek gösterilebilir. Diğer bir deyişle bir çocuk, özel yetenek alanlarının hepsinde, aynı seviyede bir ileri gelişim seviyesinde bulunamayabilir.

Özel yetenek, ortalama üstü bir gelişim sürecini, potansiyeli ve başarıyı ifade eder. Fakat özel yetenekli çocuklar, mükemmel, ciddi sorunlar yaşamayan, yetersizlik görülmeyen ve normal gelişim gösteren yaşıtlarından daha “üstün” çocuklar değildir (Rimm, Siegle, \& Davis, 2018). Dolayısıyla özellikle erken çocukluk dönemlerinde, bu çocukların çok farklı türde ihtiyaçları varmış gibi hareket etmemek gerekir. Diğer tüm çocuklar gibi özel yetenekli çocuklardan da belirli bilgileri edinmeleri ve becerileri kazanmaları beklenir. İlerleyen yaşlarda ihtiyaçlar farklılaşmaya başlasa da erken çocukluk döneminde edinilmesi gereken bilgi ve becerilerin, tüm çocuklar için aynı olduğu söylenebilir. Ancak normal gelişim gösteren yaşıtlarından faklı olarak, özel yetenekli çocuklar, bu bilgi ve becerileri edinme zamanları, edinme miktarları ve edinme hızları bakımından erken çocukluk döneminde farklılık gösterirler (Webb, Devries, Amend, \& Gore, 2007). 


\section{Çocuğumun Özel Yetenekli Olduğunu Nasıl Anlarım?}

Özel yetenek tek bir alanda görülen bir durum olmadı̆̆ı için özel yetenekli çocuklar, çok farklı profil özellikleri sergilerler. Örneğin, IQ alanında özel yetenekli olan bir çocuğun özellikleriyle müzik alanında özel yetenekli olan bir çocuğun özellikleri arasında belirgin farklar vardır. Yine de özel yetenekli çocukların, tüm alanlarda gözlemlenebilen şu özelliklerinin olduğu söylenebilir: Özel yetenekli çocuklar, özel yetenekli oldukları alana ilişkin var olan bilgi ve beceriyi, yaşıtlarına kıyasla daha erken, daha fazla olacak şekilde ve daha hızlı edinirler (Rimm ve diğ., 2018; Van Tassel-Baska \& Stambaugh, 2006; Webb ve diğ., 2007). Elbette bu ortak özelliklerin davranışlara olan yansımaları, yetenek alanlarına göre farklılık gösterir. Örneğin, müzik alanında özel yetenekli bir çocuğun yaşıtları bir şarkıyı duyduklarında sadece dinleme ve sallanarak eşlik etme davranışı sergilerken o, aynı şarkıyı melodisine dikkat ederek uygun tonlamayla doğru şekilde söyleyebilir. Ya da yaşıtları 30-40 kelimeyle iletişim kuran IQ alanında özel yetenekli bir çocuk, 150-160 kelimeyle iletişim kuruyor olabilir. Ya da psikomotor alanda özel yetenekli bir çocuk, tenisteki forehand vuruşunu daha az tekrarla çok daha ileri seviyeye getirebilir. Ayrıca yukarıdaki özelliklere ek olarak özel yetenekli çocuklar, sahip oldukları bilgi ve beceriyi yaşıtlarının ilerisinde bir seviyede kullanırlar (Webb ve diğ., 2007). Bu nedenle özel yetenekli çocuklar, yaşıtlarından daha yüksek başarılar ortaya koyarlar.

Özel yetenekli çocukların bu özellikleri erken yaşlardan itibaren sergileyebilmelerinin temel sebeplerinden biri, bu çocukların gelişim süreçlerinin yaşıtlarından daha hızlı seyretmesi ve bir sonraki gelişim basamağına yaşıtlarından daha erken erişiyor olmalarıdır (Van Tassel-Baska \& Stambaugh, 2006). Özel yetenekli çocukların, özel yetenekli oldukları alanlardaki gelişimleri, yaşıtlarının çok daha ilerisindedir. Normal dağılım eğrisini ve standart sapmayı dikkate aldığımızda, özel yetenekli bir çocuğun gelişim seviyesinin, biyolojik yaşının en az 1,3 katı seviyesinde olması gerektiğini söyleyebiliriz. Bu da yaklaşık olarak yaşının 3'te 1'i kadar daha ileri bir seviyeye tekabül eder. Örneğin, 30 aylık olan özel yetenekli bir çocuğun belirli alanlardaki gelişimi, yaşıtlarından en az 9-10 ay daha ileri seviyededir denilebilir. Çocuğun yaşı arttıkça, seviye farkının artması gerekir. Örneğin, 48 aylık bir çocuğun belirli alanlardaki gelişim seviyesi, yaşıtlarından en az 14-15 ay daha ileride olmalıdır denilebilir. Aradaki gelişim farkı daha fazla da olabilir. Gelişim farkı ne kadar fazlaysa çocuğun yeteneği de o kadar ileri seviyededir. Erken gelişimin getirdiği olgunluk, bilgi edinme ve beceri kazanma süreçlerini olumlu yönde etkiler (Webb ve diğ., 2007). sebebi ise özel yetenekli çocukların belirli beyin bölgelerinin, yaşıtlarının 
beyin bölgelerine kıyasla daha yüksek işlev kazanmasıdır (Geake, 2009). Kalıtım ve çevrenin etkisiyle yüksek işlev kazanmış beyin bölgeleri, uzun süreli bellek, çalışan bellek, uzamsal algı, dil edinimi, görsel algı, işitsel algı, psikomotor koordinasyon, ıraksak düşünme vb. gibi farklı alanlara ilişkin olabilir. Daha yüksek işlev kazanmış olan beyin bölgeleri, bilgi ve becerilerin daha fazla, daha hızlı ve daha etkili şekilde edinilmesine, işlenmesine ve kullanılmasına imkân sağlar (Geake, 2009).

Erken gelişimin ve beyindeki yüksek işlevin, bilginin ve becerinin edinme zamanını, miktarını, hızını ve kalitesini etkilemesiyle tüm özel yetenek alanlarında gözlemlenen özelliklerin yanında, sadece bir özel yetenek alanında kendini gösteren özellikler de vardır. Örneğin, IQ alanındaki özel yetenekli çocukların bazı özellikleri arasında, soyut kavramları daha erken yaşlarda anlamlandırma, olayları analiz etme ve olaylardan çıkarım yapma becerilerinin daha ileri seviyede olması, bilgiyi çalışan bellekte daha hızlı işleme, bilgiyi uzun süreli hafızadan daha kısa sürede çağırma ve okumayı yaşıtlarından erken öğrenme bulunduğu söylenebilir (Roid \& Barram, 2004). Yaratıcı düşünme alanında özel yetenekli çocukların, problemi fark etme, fazla sayıda fikir üretme, özgün fikirler üretme, sentez yapma, risk alma, imgeleme ve kıyaslama becerileri yaşıtlarından farklılık arz eder (Torrance, 1979). Benzer şekilde, liderlik, sanat, psikomotor ve akademik alanlardaki özel yeteneğin de o alana ilişkin ayrı belirtileri mevcuttur. Bazen bir özellik, birden fazla alanda gözlemlenebilir. Bir anne-baba, çocuklarının belirli alanlardaki bilgi ve becerileri, yaşıtlarına kıyasla daha erken, daha fazla ve daha hızlı edindiğini gözlemler ve kendilerinden daha büyük çocukların sergilediği bazı özellikleri sergilediğini görürse çocuklarının özel yetenekli olduğundan şüphelenip bir uzmana başvurabilir.

\section{Çocuğuma Test Yaptırmalı Mıyım?}

“Acaba çocuğuma test yaptırsam mı?” sorusu, çocuklarının özel yetenekli olduklarından şüphelenen ebeveynlerin akıllarına gelen ilk sorulardan birisidir. Uzman olduğunu düşündükleri birine danıştıklarında da genellikle gelen cevap, "Tabii ki! Şu testlerden birini yaptırıp çocuğunuzun özel yetenekli olup olmadığını öğrenebilirsiniz." olarak karşımıza çıkmaktadır. Bu cevapla birlikte gelen öneriler, çoğunlukla IQ testi olmaktadır çünkü hâlâ birçok kişi tarafından, özel yetenekli çocukların hepsinin "üstün zekâlı" olduğu düşünülmektedir. Ancak bu soruyu soran bir ebeveyne verilmesi gereken cevap, “Çocuğunuzun özel yetenekli olup olmadığını öğrenmek için çocuğunuzu elbette bir uzmanın değerlendirmesini öneririm ama bu değerlendirme illa ki bir test, özellikle de IQ testi, aracılığıyla olmak zorunda değil." olmalıdır. 


\section{IQ Testleri İle Tanılama}

IQ testleri, özel yetenekli çocukları tanılamak için hem ülkemizde hem de dünyada en çok kullanılan ölçme araçlarıdır. Tanı almak için sadece IQ testi yaptırmanın en sınırlayıcı yanı, IQ testlerinin ölçüm yaptığı becerilere ilişkindir. IQ testleri, adından da anlaşılacağı üzere IQ ile ilişkili olan becerilerin seviyesinin belirlendiği testlerdir. Dolayısıyla IQ testleri, güvenilir ve geçerli sonuçlar vermeleri kaydıyla IQ alanında özel yetenekli olan çocukları tanılamak için kullanılabilir. Ancak yukarıda da değinildiği üzere özel yetenekliler grubu, sadece yüksek IQ sahibi olan çocuklardan meydana gelmez (Gagné, 2004; Gardner, 1983; Marland, 1972; MEB, 2018; Renzulli, 1986; Sternberg, 2005). Ortalamanın üstünde bir zihinsel gelişim gösterip de IQ'nun dışındaki alanlarda özel yetenekli olan çocuklarla da karşılaşılmaktadır.

IQ seviyesi, her ne kadar diğer alanlardaki gelişim üzerinde belirli oranda etkili olsa da IQ testleri, diğer alanlardaki özel yetenek potansiyeline ilişkin bilgi vermez. Örneğin, ortalama üstü bir zihinsel gelişim gösteren ama yaratıcı düşünme alanında özel yetenekli olan bir çocuk, IQ testinden beklenen puanı (IQ > 130) elde edemeyecektir. Böyle bir durumda da anne-baba, çocuklarının özel yetenekli olmadığını düşünecek ve belki de çocuklarının yaratıcı düşünme alanında var olan potansiyelini ortaya koyması için onu desteklemeyi ihmal edecektir. Sadece IQ testi ile tanılama yapmak, yüksek IQ sahibi olmayan ama diğer alanlarda özel yetenekli çocukların gözden kaçmasına sebep olacaktır.

IQ testlerinin tercih edilmelerinin bazı önemli nedenleri vardır. Bu testlerin kısa süre içerisinde yapılabilmesi, objektif bir değerlendirme sonucu sunması, çocuğu yaşıtlarıyla karşılaştırarak onun hangi seviyede olduğunu göstermesi ve toplumun IQ'ya atfettiği önem, IQ testlerinin yaygın kullanımlarının en önemli nedenleri olarak karşımıza çıkmaktadır. Ancak bu testlerin, sadece IQ alanına ilişkin bilgiler sunması sebebiyle diğer alanlardaki özel yetenekli çocukların keşfedilebilmesi için başka değerlendirme araç ve yöntemlerinin kullanılması kaçınılmaz hale gelmektedir.

\section{Gelişim Testleri İle Tanılama}

Okul öncesi dönemde, IQ testi dışında kullanılabilecek bir diğer araç türü gelişim testleridir. Gelişim testleri, farklı gelişim alanlarında, çocuğun o andaki seviyesiyle alakalı bilgi veren ölçme araçlarıdır. Ölçüm yapılan alanlar, bilişsel, dil, ince motor, kaba motor, görsel algı, uzamsal algı, görsel hafıza vb. gibi farklı gelişim alanlarında olacak şekilde karşımıza çıkar (bkz. 
Denver Gelişimsel Tarama Testi; Metropolitan Olgunluk Testi). Bu açıdan bakıldığında, gelişim testlerinin IQ testlerinden daha geniş bir yelpazede bilgi sunduğu söylenebilir. Ancak gelişim testleri doğru kullanılmadı̆̆ı zaman, uygulayıcıyı yanıltıcı sonuçlara götürür.

Gelişim testlerinin kullanımında dikkat edilmesi gereken en önemli hususlardan biri, gelişim testinin uygulanabileceği maksimum yaş sınırı ve testin uygulanacağı çocuğun yaşıdır. Gelişim testleri, genellikle okul öncesi dönemdeki gelişim seviyesini belirlemek için kullanılır ve ölçüm yaptıkları en üst yaş sınırları çok yüksek değildir (bkz. Denver Gelişimsel Tarama Testi; Metropolitan Olgunluk Testi). Örneğin, 6 yaşına kadar olan gelişimi ölçmek için geliştirilmiş olan bir gelişim testinin uygulandığı çocuk 5 yaşlarında olan bir çocuksa bu çocuk, testin sonucuna göre özel yetenek tanısı alamayacaktır. Çünkü çocuk, ölçüm yapılan alanlarda biyolojik yaşının 3-4 yaş ilerisinde bir gelişim seviyesine sahip olsa bile kullanılan test, 8-9 yaş seviyesine ilişkin bir bilgi vermemektedir. Bu sebeple gelişim testlerini kullanırken, çocuğun biyolojik yaşının ilerisinde bir gelişim seviyesi hakkında bilgi verebilen testlerin kullanımına dikkat edilmelidir.

\section{Yaratıcı Düşünme Testleri İle Tanılama}

Yaratıcı düşünme testleri, ağırlıklı olarak ıraksak düşünme becerilerini ölçen testlerdir. Iraksak düşünme becerisi, herhangi bir soruya cevap veya herhangi bir probleme çözüm olabilecek alternatif fikirler üretme becerisidir (Guilford, 1959). Iraksak düşünme, yaratıcı düşünmenin alt beceri gruplarından biri olsa da yaratıcı düşünmenin ortaya çıkması için olmazsa olmaz kabul edilen becerileri içerir (Runco \& Jaeger, 2012). Bu sebeple, ıraksak düşünme testleri, çocuğun yaratıcı düşünme potansiyelini belirlemek için kullanılabilir. Ancak şu da belirtilmelidir ki yaratıcı düşünme testleri, IQ ve gelişim testleri kadar geniş bir seçeneğe sahip değillerdir.

\section{Portfolyo Değerlendirmeleri İle Tanılama}

IQ gelişim ve yaratıcı düşünme testleri dışında kullanılabilecek yöntemlerin en dikkate değer olanlarından biri portfolyo değerlendirmesidir (Moon, 2012). Portfolyolar, çocukların belirli bir süre zarfında ortaya koydukları ürünlerin arşivlendiği dosyalardır (Moon, 2012). Bu arşivleme, okul öncesi dönemde aileler tarafından yapılmaktadır. Bu yüzden, okul öncesi dönemde, ailelerin çocuklarını dikkatlice gözlemlemeleri ve çocuklarının ortaya koyduğu ürünleri uygun şekilde arşivlemeleri, portfolyo değerlendirmesi yapmak için önem arz eder. 
Portfolyo dosyaları, çocuğun bir veya birkaç yıl gibi belirli bir süre zarfında ortaya koyduğu ürünleri içerir (Moon, 2012). Bu dosyalar yazılı, işitsel veya görsel içeriklerden oluşabilir ve çocuğun hangi dönemde hangi seviyede bir ürün ortaya koyduğunu gösterir. Portfolyo dosyası oluşturan ailelerin, ürünlerin hangi yaş ve ayda ortaya konduğunu kayıt altına alması bu açıdan önemlidir. Çocuğun ortaya koyduğu ürün, söylediği şarkılar, sergilediği dans figürleri, psikomotor alanda ortaya koyduğu davranışlar, yaptığı resimler vb. gibi farklı türde olabilir (Moon, 2012).

Portfolyodaki ürünler, çocuğun doğal ortamında ortaya koyduğu ürünler olduğu ve çocuğun gelişim sürecini de gösterdiği için çocuk hakkında detaylı bilgiler sunar (Moon, 2012). Ayrıca portfolyolar, doğru bir arşivleme yapıldığında yaratıcı düşünme, resim, müzik, liderlik, spor ve akademik alanlar da dâhil olmak üzere çok geniş bir alanda değerlendirme imkânı sunabilir. Bu değerlendirme, alan uzmanları tarafından gerçekleştirilir. Uzman, çocuğun var olan seviyesini, normal gelişim gösteren yaşıtlarının seviyesiyle kıyaslayarak çocuğun özel yetenekli olup olmadığı hakkında görüş belirtir (Moon, 2012). Değerlendirme süreçlerinde, değerlendirme yapılan alana ve çocuk gelişim sürecine hâkim uzmanlara ulaşma gerekliliği, portfolyoların kullanımının sınırlılıklarının en önemlilerinden biridir.

\section{Tanılama İçin İkinci Bir Değerlendirme Yapmak}

Özel yetenekli olduğundan şüphelenilen bir çocuk, uygulanan test sonucunda özel yetenek tanısı almasını sağlayacak puanı elde edemediyse bunun birçok sebebi olabilir. Çocuklar, açlık, kaygı, yorgunluk vb. gibi sebeplerden dolayı, var olan potansiyellerinin çok altında bir test performansı sergileyebilir. Ya da bazen testin kendisinden veya testi uygulayan kişiden kaynaklanan sebepler dolayısıyla çocuğun aldığı puan, çocuğun gerçek potansiyelini doğru şekilde yansıtmaz. Böyle bir durumda, ikinci bir değerlendirme yapılması söz konusu olabilir. Test öncesi yapılan gözlemler, çocuğun yaşının çok ilerisinde bir gelişim seviyesinde olduğuna ilişkin kanıtlar sunuyorsa çocuğun yetenekli olduğu alana ait farklı ölçme araçları veya yöntemleriyle ikinci bir değerlendirme yapmakta fayda vardır.

Bazen bir çocuğun yeterli puanı alamamasındaki temel sebep, çocuğun özel yetenekli olmamasıdır. Böyle bir durumda, çocuğu sürekli olarak bir değerlendirmeye tabi tutmak, bu süreçte çocuğa karşı gerçek dışı beklentilerin oluşturulmasına sebep olarak çocuk üzerinde olumsuz sonuçlar doğurabilir. Unutulmamalıdır ki bir çocuğun özel yetenekli olup olmadığının değerlendirilmesinin temel amacı, bu çocuğun potansiyeliyle alakalı bir fikir sahibi olmaktır (Rimm ve diğ., 2018). Çocuğun yetenekli olduğu 
düşünülen alana ilişkin yapılan bir değerlendirme, çocuğu daha detaylı bir şekilde tanımaya, neler başarabileceğine ilişkin öngörülerde bulunmaya ve seviyesine uygun düzenlemeler yapmaya yardımcı olur. Bir testin sonucunda alınan özel yetenek tanısı, çocuğun kesinlikle yüksek başarılar ortaya koyacağını garanti etmez (Mackintosh, 2011). Benzer şekilde, değerlendirme sonucunda özel yetenek tanısı alamayan bir öğrenci de başarısız değildir. Önemli olan husus, çocuğu bir teste sokarak veya başka bir değerlendirmeye tabi tutarak özel yetenek tanısı aldırmak değil, değerlendirmeyi yaptıktan sonra, çocuk özel yetenek tanısı alsa da almasa da çocuğu gereğince desteklemek ve potansiyelini performansa dönüştürmesini sağlamaktır.

\section{Çocuğuma Neler Öğretmeliyim?}

Çocuklarının özel yetenekli olduğunu öğrenen ailelerin birçoğu, kendilerine ve alan uzmanlarına bu soruyu sormaktadır. Bu soru, özellikle IQ alanında özel yetenekli olan çocukların ebeveynlerinden, öncelikli olarak akademik içeriklerin öğretilmesine ilişkin gelmektedir. Bunun temel sebebi de IQ alanında özel yetenekli olan birçok çocuğun, 4 yaşlarında bile okumayı ve temel matematik kavramlarını öğrenebilecek seviyede olmasından kaynaklanmaktadır (Robinson, 1993). Aileler, akademik bir içerik öğreterek, hem çocuklarının öğrenme ihtiyaçlarını karşılamak hem de yaşıtlarından daha ileride olmalarını sağlayarak akademik başarılarını artırmak istemektedirler (Robinson, 1993).

IQ okul ve iş başarısıyla en çok ilişkilendirilen kavram olarak karşımıza çıkar (Richardson \& Norgate, 2015). Araştırmaların tamamı, IQ ve ilerleyen yaşlardaki başarı arasında pozitif yönlü bir korelasyon rapor etmiştir (Bertua, Anderson, \& Salgado, 2005; Mackintosh, 2011; Rhode \& Thompson, 2007; Schmidt \& Hunter, 2003). Diğer bir deyişle çocuğun sahip olduğu IQ seviyesi, onun okul ve iş hayatında ne kadar başarılı olacağı hakkında belirli ölçüde tahminlerde bulunmamızı sağlar. IQ seviyesi, çocuğun potansiyeli hakkında bilgi verir ama bu potansiyelin başarıya dönüşmesi için tek etken IQ değildir (bkz. Rhode \& Thompson, 2007).

IQ ile gelecek başarısı arasındaki pozitif yönlü ilişkinin sebeplerinden biri, IQ seviyesinin artmasıyla birlikte, edinilen bilgi ve becerilerin miktarıla birlikte niteliğinin de artma olasılığının yükselmesidir. IQ alanındaki özel yeteneğin, diğer alanlardan daha çok önemsenmesinin en önemli gerekçelerinden biri budur. Bu sebeple birçok ebeveyn, çocuklarının belirli seviyenin üstünde bir IQ'ya sahip olmalarını ister. Çünkü aileler, yüksek IQ sahibi olan bir çocuğun, ilerleyen yaşlardaki başarısının da yüksek olacağını düşünmektedir. Her ne kadar bu bakış açısı tamamen yanlış olmasa da IQ, 
ilerleyen yaşlarda ortaya koyulan başarıları açıklayan değişkenlerden sadece biridir. Araştırmalar, IQ seviyesinin, gelecekteki başarıyı en fazla \%25-30 oranında açıklayabildiğini ortaya koymaktadır (Mackintosh, 2011). Geriye kalan \%70-75'lik kısım ise başka değişkenlerden etkilenir. Bu değişkenlerin bazıları çocukla, bazıları aileyle, bazıları öğretmenle ve bazıları diğer çevresel etmenlerle ilişkilidir (bkz. Hattie, 2009). Ayrıca, unutulmamalıdır ki okul ve iş hayatındaki başarı, her zaman mutlu bir hayat anlamına gelmez. Hem başarılı hem de mutlu bir hayat için yüksek bir IQ'dan ve öğrenilmiş bilgiden daha fazlası gerekir. Dolayısıyla "Çocuğuma neler öğretmeliyim?” sorusunu, sadece IQ puanı, IQ alanındaki özel yetenekli çocuklar ve akademik içeriğin öğretilmesini dikkate alarak cevaplamak çok da doğru bir bakış açısı olmayacaktır. Bu soruyu cevaplarken ilerleyen yaşlardaki başarıyı ve hayat kalitesini IQ dişındaki hangi değişkenlerin etkilediğine bakmak, aileleri daha doğru bir yola iletecektir. Böylece, özel yetenekli çocukların gelişimi daha kapsamlı bir şekilde desteklenebilir.

\section{Başarıyı ve Hayat Kalitesini Etkileyen Değişkenler}

Akademik başarıyı etkileyen değişkenlere baktığımızda, karşımıza uzun bir liste çıkar. Örneğin, Hattie (2009), 800'den fazla meta-analiz çalışmasını inceledikten sonra 250'nin üstünde değişken tespit etmiştir. Bunlardan 41 tanesi, öğrenenle yani çocukla ilişkilidir (Hattie, 2009). Ancak unutulmamalıdır ki hayatın içerisindeki değişkenler, çalışmalarda belirlenen bu sayılarla sınırlı değildir.

Başarıyı ve hayat kalitesini etkileyen değişkenlerden çocukla ilgili olanları dört ana grupta ele alabiliriz. Bunlar, yetenekler, benlik kavramı, öz düzenleme ve erdem davranışlarıdır. Bu değişken gruplarının önemi, farklı araştırmacılar tarafından da vurgulanmıştır (Renzulli, 1986; Schunk, 2012; Sternberg, 2005). Örneğin, Schunk (2012) öz yeterlilik, öz güven ve öz saygıdan oluşan benlik kavramının, başarıyı ve kendini gerçekleştirmeyi etkileyen önemli bir değişken olduğu görüşünü benimsemiştir. Diğer taraftan Renzulli (1986), öz düzenleme içerisinde değinilecek olan göreve adanmışlığın, özel yetenek kavramının önemli bir bileşeni olduğunu ifade etmiştir. Sternberg (2005) ise bilgelik kavramını öne sürerek erdemli davranışların özel yetenekli bireyler için önemini ortaya koymuştur.

Yukarıdaki görüşleri destekleyen araştırmalar da vardır. Hattie (2009) tarafından yapılan meta-analiz çalışmasında, akademik başarıyı pozitif yönde en çok etkileyen değişkenler arasında öz yeterlilik, çaba gösterme ve motivasyon göze çarpmaktadır. Öz yeterliliğin başarı üzerindeki etkisi, diğer araştırmacılar tarafından da tespit edilmiştir (bkz. Lee \& Shute, 
2010; Lee \& Stankov, 2018; Richardson, Abraham, \& Bond, 2012; Stankov, 2013). Öz yeterliliğin, ortaya koyulan başarının \%25'lik bir kısmını tek başına açıklayabildiğini gösteren bulgular vardır (Pintrich, 1999). Metaanaliz çalışmalarında, başarıya en çok pozitif katkı sağladığı tespit edilen diğer değişkenler arasında çalışma disiplini (Richardson ve diğ., 2012), ilgi duyduğu alanı öğrenme ve süreçten haz duyma (Lee \& Shute, 2010) gelmektedir.

IQ dışındaki değişkenler, başarıyı sadece kısa vadede değil, uzun vadede de olumlu yönde etkilemektedir. Buna ilişkin en önemli bulgulardan biri, Shiner, Masten ve Roberts (2003) tarafından yürütülmüş olan çalışmada karşımıza çıkmaktadır. Yirmi yıllık bir süreci kapsayan bu çalışmada, çocukların 10 yaşında sergiledikleri belirli özelliklerin, bu çocuklar 30 yaşına geldiğinde sahip oldukları okul ve iş başarısı üzerindeki etkisi araştırılmıştır. Başarı üzerinde etkisi araştırılan değişkenler, motivasyon, akademik bilinç, sosyal beceriler ve uyum adı altında dört grupta toplanmıştır. Motivasyon içerisine, verilen görevleri hevesle, yaratıcı şekilde, kendine güven duyarak ve istikrarlı bir şekilde yerine getirme becerileri dâhil edilmiştir. Akademik bilinç, okul yaşantısına ciddi ve sorumlu bir şekilde yaklaşmayı içermektedir. Sosyal beceriler, içe dönük olmaktan ziyade dışa dönük olmayı, pasif olmaktan ziyade aktif olmayı, okul devamsızlığından ziyade devamlılığı ve bir işi tamamlamak için kendini başkalarına muhtaç hissetmekten ziyade kendine yetmeyi içermektedir. Uyum adı altında da belirlenen kurallara eşlik etme, cömert, nazik ve düşünceli olma özellikleri vardır. Araştırma bulgularına göre yukarıdaki dört ana değişkenin her biriyle akademik başarılar ve iş başarısı arasında pozitif yönlü anlamlı ilişkiler bulunmuştur.

Akademik içerikle erken yaşlarda tanışmak, gelecek başarısı üzerinde etkili olsa da farklı nedenlerle çocukların hayat kaliteleri üzerinde beklenmeyen etkiler oluşturabilir. Örneğin, Kern ve Friedman (2008) tarafından yapılan araştırma, buna ilişkin ipuçları sunmaktadır. Bu araştırmada, okumayı erken öğrenen ve okula erken başlayan çocuklarla normal gelişim gösteren çocukların eğitim seviyeleri ve ergenlikten yetişkinlik dönemine kadarki toplumsal uyumları karşılaştırılmıştır. Çalışmadaki ilk veriler, 1920'li yıllarda toplanmıştır. Takip eden 80 yıllık süreçte de hayatta olan katılımcılardan veri toplanmaya devam edilmiştir. Okumayı erken öğrenen ve okula erken başlayan çocuklar, daha iyi bir eğitim seviyesine erişmiş olmalarına rağmen ergenlik ve yetişkinlik dönemlerinde toplumsal uyum becerileri bakımından daha düşük performans sergilemişlerdir. Elde edilen bu bulgu, erken yaşta okumanın ve akademik becerileri erken yaşta edinmiş olmanın, bu çocukların ileriki yaşlarında gösterdikleri düşük uyum seviyesinin direkt sebebi olduğu anlamına gelmemektedir. Ancak bu bulgu, 
akademik içeriğin çocuğa erken yaşlarda verilmesinin, hem başarıyı hem de hayat kalitesini kesin olarak artırmayacağını ve başka değişkenlerin de dikkate alınması gerektiğini göstermektedir.

Bulguları paylaşılan yukarıdaki çalışmalar gibi sayısı azımsanamayacak kadar çalışma vardır (bkz. Lee, 2009; Richardson ve diğ., 2012; Stankov, 2013). Bu çalışmaların önemli bir kısmı, başarının ve hayat kalitesinin, IQ ve öğrenilmiş bilgi dışındaki değişkenlerden de önemli ölçüde etkilendiğini ortaya koymaktadır. Diğer bir deyişle "Başarılı olmak için zeki olmak yeterlidir." şeklindeki bir bakış açısı, değişmesi gereken bir bakış açısıdır. Var olan çalışmaların bulgularını dikkate alarak, "Çocuğuma neler öğretmeliyim?” sorusunu, yukarıda değinilmiş olan dört değişken grubuna vurgu yaparak cevaplamak mümkündür.

\section{Akademik İçeriğin Öğretilmesi ve Yeteneğin Geliştirilmesi}

Eğer bir çocuk IQ alanında özel yetenekliyse çocuğun gelişim seviyesi, okuma, yazma ve matematik gibi akademik becerileri yaşıtlarından daha erken yaşlarda edinmesine imkân sağlayacaktır. Akademik içeriği yaşıtlarından daha erken yaşlarda öğrenmek, IQ alanında özel yetenekli olan çocukların gereksinimlerinden biridir (Robinson, 1993). Bu tür gereksinimleri olan çocukların aileleri, kendilerini donanımlı görüyorsa çocuklarını belirli akademik içerikle erken yaşlarda tanıştırabilir ya da bunun için bir profesyonelden yardım alabilirler. Akademik içeriğin çocuklara verilmesi sürecinde çocukların ilgilerinin dikkate alınması, süreci onlar için hem daha eğlenceli hem de daha verimli hale getirir (Lee \& Shute, 2010; Ryan \& Deci, 2000).

Sunulan akademik içeriğin revize edilmiş olan Bloom taksonomisindeki sıralamayla kazandırılması, çocukların bilgiyi derinlemesine öğrenmelerini sağlayacaktır. Bloom'un taksonomisinin takip edilmesi, bilgiye ulaşmanın değil, bilgiyi üretken şekilde kullanmanın önemli olduğu günümüz dünyasında, özel yetenekli çocukların daha donanımlı bir şekilde yetişmelerine de yardımcı olacaktır. Bloom, bilginin öğrenilmesini seviyelere ayırmıştır (Bloom, Engelhart, Furst, Hill, \& Krathwohl, 1956). Revize edilmiş taksonomideki seviyeler sırasıyla şunlardır: hatırla, anla, uygula, analiz et, değerlendir ve üret (Anderson \& Krathwohl, 2001). En düşük seviyede, bilgi ezberlenmiştir ve gerektiğinde aynen tekrar edilir (Anderson \& Krathwohl, 2001). Sonraki basamaklarda çocuk, sırasıyla öğrendiği bilgiyi kendi yorumuyla açıklar, farklı durumlara genelleyerek bir işlem gerçekleştirir, ilişkiler kurarak analiz eder, yaptığı kıyaslar sonucunda dayanağı olan bir sonuca ulaşır ve özgün bir biçimde kullanarak ortaya yaratıcı bir ürün koyar (Anderson \& Krathwohl, 2001). 
IQ alanındaki özel yetenekli çocukların Piaget'in (1971) gelişim dönemlerinde okul öncesinde ulaştıkları seviye düşünüldüğünde, bu çocukların, edindikleri bilgiyi somut ve basit olacak şekilde Bloom taksonomisindeki basamaklara göre kullandığı söylenebilir. Bu çocuklar bir gelişim dönemine yaşıtlarından erken girdikleri için okul öncesinde, somut işlemler dönemine erişebilirler ve bir mantık çerçevesinde öğrendikleri bilgiyi somut olarak kullanabilirler (Van Tassel-Baska \& Stambaugh, 2006). Ancak özel yetenekli çocukların öğrendikleri bilgileri, bir yetişkin gibi kapsamlı ve soyut mahiyetlerini dikkate alarak kullanmaları söz konusu olmayacaktır. Ayrıca analiz etme, değerlendirme ve üretme basamakları, farklı aşamaları olan ve farklı üst düzey bilişsel becerinin bir arada kullanımını gerektiren basamaklardır (Anderson \& Krathwohl, 2001). Bu sebeple IQ alanında özel yetenekli olan okul öncesi çocukları, bilginin analiz edilmesi, değerlendirilmesi ve kullanılarak özgün bir ürünün üretilmesi için yetişkin yönlendirmesine özellikle ihtiyaç duyarlar.

Bloom taksonomisi, bilginin öğrenilmesiyle alakalı bir öncelik sonralık ilişkisi ortaya koyduğu için öncelikle çocuğun bilgiyi ilk üç basamaktakine uygun şekilde öğrenmesine ve kullanmasına yönelik imkânlar sunulmalıdır. Ardından, bilginin diğer basamaklara uygun şekilde kullanılması gelmelidir. IQ alanındaki özel yetenekli çocukların bilişsel gelişimleri, yaşları ilerledikçe bilginin daha kapsamlı ve soyut seviyede kullanılarak analiz edilmesine, değerlendirilmesine ve özgün bir ürün üretilmesine imkân verecek seviyeye ulaşır (Van Tassel-Baska \& Stambaugh, 2006). Bu sebeple aileler ve profesyoneller, çocukların bilişsel gelişimlerini yakından takip etmeli ve seviyelerine uygun şekilde bilgiyi kullanmalarını sağlayacak şekilde onları yönlendirmeli ve desteklemelidir.

IQ dışındaki alanlarda özel yetenekli olan çocukların zihinsel gelişimleri, onların okuma, yazma ve matematik gibi alanlardaki kapsamlı içeriklerle çok erken yaşta tanışmalarına imkân verecek seviyede olmayacaktır. Çünkü IQ seviyeleri normal kabul edilen sınırlar içinde veya normalin üstünde olan bu çocukların zekâ yaşları, IQ alanında özel yetenekli olan çocukların zekâ yaşları kadar yüksek değildir. Bu çocuklar, ilkokula normal veya normalüstü bir gelişim gösteren diğer ama bir alanda özel yetenekli olmayan çocuklarla benzer bilgi seviyesinde başlarlar. Ancak bu çocukların, özel yetenekli oldukları alanlara ilişkin gereksinimlerinin olduğu unutulmamalıdır (Rimm ve diğ., 2018). Bu gereksinimlerin ve çocuğun bu alandaki özel yeteneğinin aile tarafından önemsenmesi, bu çocukların doğru şekilde desteklenmesi için elzemdir. Bu özel yetenek alanlarında kendini donanımlı gören aileler veya çocuğun yetenekli olduğu alanda çalışan profesyoneller, uygun bir içeriği çocuğa sunabilirler. 
Sonraki değişken grubuna geçmeden önce sosyal ve duygusal ihtiyaçlara da değinmek faydalı olacaktır. Hem IQ alanında hem de diğer alanlarda özel yetenekli olan çocukların özel yetenek alanlarıyla direkt ilişkili ihtiyaçlarının yanında, sosyal ve duygusal ihtiyaçları da eşit derecede önemlidir (Cross, 2018). Unutulmamalıdır ki özel yetenekli çocuklar, her şeyden önce çocuktur. Bu sebeple çocuğa, özel yetenekli olduğu alanla ilişkili bir içeriği öğretmenin yanında onun çocukluğunu da doyasıya yaşaması sağlanmalı, sosyal ve duygusal alanlardaki gelişimi de desteklenmelidir.

Yetenek alanlarına ilişkin kazanımları gereğinden fazla önemseyen ailelerin, çocuklarının üzerinde oluşturdukları baskı ve çocuğa çocukluğunu yaşaması için yeterli imkânları sunmamaları, çocuklarının sağlıklı bir çocukluk, ergenlik ve yetişkinlik dönemi yaşamasını sekteye uğratabilir. Bu durum da bu çocukların hayat kalitelerini ve mutluluklarını olumsuz yönde etkileyecektir. Kern ve Friedman (2008) tarafindan yapılan ve yukarıda değinilen çalışmadan yapılacak önemli çıkarımlardan biri de budur.

Sosyal ve duygusal gelişimin desteklenmesi, IQ alanında özel yetenekli çocuklar için ayrıca önemlidir. Belirli akademik becerileri okula başlamadan öğrenen çocukların neredeyse tamamı, 1. sınıfı atlayarak 2. sınıftan devam edebilecek bir akademik seviyede olurlar. Ancak sınıf atlatmanın çocuk üzerinde olumsuz sonuçlar doğurmaması için çocuğun sosyal ve duygusal gelişiminin de 2. sınıftaki öğrencilerin becerilerine ayak uydurabilecek seviyede olması önemlidir (Rimm ve diğ., 2018).

\section{Benlik Kavramı}

Benlik kavramı, çocuğun kendisiyle alakalı var olan genel algısıdır (Schunk, 2012). Benlik kavramı, farklı bileşenlerden oluşur. Öz yeterlilik, öz güven ve öz saygı, benlik kavramı içerisinde en dikkat çeken ve olumlu yönde geliştirilmesi gereken bileşenlerdir (Schunk, 2012). Öz yeterlilik olarak adlandırılan kavram, çocuğun yeteneklerini dikkate alarak bir işi başarabileceğine olan inancını ifade eder (Schunk, 2012; Bandura, 1997). Kendini yeterli görmeye yönelik bu inanç, başarılı girişimlerle desteklendiğinde, başarılı olacağından emin olmaya yani öz güvene dönüşür (Mowlaie, Besharat, Pourbohlool, \& Azizi, 2011). Öz saygı ise çocuğun, sahip olduğu tüm özelliklerini dikkate alarak kendine verdiği bütünsel değerdir (Schunk, 2012).

Çocuk ve Medeniyet 2020/2
Önceki paragraflarda, öz yeterliliğin başarıyı getiren önemli değişkenlerden biri olduğuna değinilmiş ve bazı araştırmalara atıfta bulunulmuştu. Öz yeterlilik, elde edilen akademik başarıyı etkilemenin yanında, çaba 
göstermeyi ve göreve adanmışlığı da olumlu yönde etkiler (Bandura \& Cervone, 1983; Pintrich \& Schrauben, 1992; Schunk, 1995) çünkü öz yeterliliğin yüksek olduğu durumlarda, çocuk var olan zorluklarla baş edebileceği inancına sahip olur.

Öz yeterlilik, alana ilişkin bir değişkendir (Schunk, 2012). Örneğin, bir çocuğun öz yeterliliği, şarkı söyleme konusunda yüksek olabilirken dans etme konusunda aynı seviyede olmayabilir. Bu yüzden, çocuğun yetenek alanlarındaki seviyesi dikkate alınarak, farklı alanlarda belirli seviyede bir öz yeterlilik kazanması için imkânlar sunmak, çocuğun sağlıklı bir benlik kavramı oluşturmasına yardımcı olacaktır.

Anne-babalar, Bandura'nın (1997) ortaya attığı dört farklı yolla çocuklarının öz yeterliliklerini artırmalarına ve öz güven kazanmalarına yardımcı olabilirler. Bunlar, ustalık deneyimleri, dolaylı deneyimler, sözlü ikna ve duygusal durumdur (Bandura, 1997). Ustalık deneyimleri, belirli seviyedeki bir işi başarmayla ilişkilidir. Çocuğa, başaracağı zorlukta görevler verilmesi hem öz yeterliliğin artmasını hem de öz yeterliliğin getirdiği inancın, "Başaracağımı biliyorum." duygusuna yani öz güvene dönüşmesini sağlayacaktır.

Dolaylı deneyimler, çocukların kendileri dışındaki kişilerin yaptıklarıyla ilişkilidir (Bandura, 1997). Anne-babalar, çocukların rol modelleri olarak, harcadıkları eforlarla belirli şeyleri başarabildiklerine ilişkin çocuklarına örnek olabilir ve öz yeterliliklerini destekleyebilirler. Zimmerman ve Ringle (1981) tarafından yapılan çalışmada, bir işi yaparken kendine güven ifadeleri kullanan yetişkinleri gören çocukların öz yeterliliklerinin arttığı bulunmuştur. Aynı çalışmada, yetişkinlerin kendilerine güven duymadıklarını yansıtan ifadelerine maruz kalan çocukların öz yeterliliklerinde düşüş meydana gelmiştir.

Sözlü ikna da öz yeterliliği artırmanın bir başka yoludur (Bandura, 1997). Çocuklar, bir işle alakalı, anne-babalarından ve kendilerine rol model olarak seçtikleri diğer yetişkinlerden gelen cesaret verici geri bildirimler sayesinde, o işi yapabilecekleri inancına sahip olmaya başlarlar ve öz yeterlilikleri yükselir. Bu sözlü ikna sürecinin ardından deneyim sunulması da önemlidir.

Öz yeterlilik kişinin içinde bulunduğu duygusal durumdan da etkilenir (Bandura, 1997). Çocuğa sunulan ortam, çocukta stres, çaresizlik ve kaygı oluşturuyorsa bu ortam öz yeterliliği olumsuz yönde etkiler. Bu yüzden aileler, evdeki ortamın mümkün olduğunca stresten uzak, sevgi dolu, cesaretlendirici, kabul edici ve teşvik edici olmasına dikkat etmelidir (Schunk, 2012). 


\section{Öz Düzenleme}

Diğer değişken grubu, öz düzenleme altında değinilecek olan ve başarıyı destekleyen niteliklerden oluşmaktadır. Öz düzenleme, hedeflere ulaşabilmesi için kişinin davranışlarını, tercihlerini ve duygularını yönetme yeterliliğidir (Bandura, 1986; Schunk, 2012). Bu yeterlilikler arasında yer alan göreve adanmışlık, çalışma becerileri, etkili zaman yönetimi vb. nitelikler hedeflere ulaşılabilmesi için kritik öneme sahiptir. Araştırmaların da vurguladığı gibi çocukların bu tür becerilere sahip olmaları, var olan yüksek potansiyellerini yüksek başarılara dönüştürmeleri konusunda onlara önemli katkılar sağlayacaktır (Lee \& Shute, 2010; Lee \& Stankov, 2018; Richardson ve diğ., 2012; Stankov, 2013). Öz düzenleme altındaki nitelikler, bir çocuğu özel yetenekli yapmaz ama özel yeteneğin getirdiği yüksek potansiyelin, yüksek bir performansa dönüşmesi sürecinde çok önemli bir yere sahiptir.

\section{Erdem Davranışları}

Hayatı asıl yaşanabilir yapan, fiziksel ve teknolojik imkânlar değil, toplumun bir harmoni içinde fonksiyon göstermesidir. Bunu sağlamanın en ideal yolu da tüm bireylerin erdemli davranışlar sergilemesinden geçer. Erdem, insanın insanca davranmasıdır (Comte-Sponville, 2020). Erdemli davranışlar da kişinin bu yönde hareket etmesini sağlar. Bir insan, sadece kendini düşünerek değil, toplumdaki diğer kişileri de dikkate alarak hareket etmeli ve başkalarına de katkısı olan ve onlara zarar vermeyen ürünler ortaya koymalıdır (Sternberg, 2005).

Kazandırılması gereken erdem davranışları arasında, nezaket, vefa, cesaret, adalet, cömertlik, merhamet, alçakgönüllülük, hoşgörü vb. davranışlar bulunmaktadır. Hem özel yetenekli çocukların hem de normal gelişim gösteren çocukların aileleri, daha huzurlu ve mutlu bir yaşam için erdem davranışlarını, çocuklara erken yaşlarda kazandırmaya ve uygulatmaya önem vermelidir. Böylece toplum, herkes için yaşanabilir bir yapı haline gelir. Shiner ve diğ. (2003) tarafından da ortaya konulduğu gibi erdem davranışları, çocuğun okul ve iş başarısını da olumlu yönde etkileyecektir.

Çocuklara, erdem davranışlarını kazandırma görevi ebeveynlere aittir. Küçük çocukların öğrenmeleri, üç farklı yolla edindikleri bilgileri yorumlayarak gerçekleşir: görerek, dinleyerek ve yaparak. Bu yolların hepsinde anne-babalar önemli bir yer tutar. Çünkü anne-babalar, çocuğun birincil bilgi kaynağıdır. Çocuklar, anne-babalarını izleyip, anne-babalarının açıklamalarını dinleyip, kendileri bir şey deneyip ve anne-babanın yaptığına karşı verdiği tepkilerden elde ettikleri bilgileri yorumlayıp çıkarım yaparak 
öğrenirler. Bunlara bir de televizyon ve video platformlarından edinilen bilgiler eklenebilir. Aileler, örnek olarak, açıklayarak ve çocuğun yaptıklarına uygun tepkiler vererek çocuklarına erdem davranışlarını kazandırılabilir. Çocukların kendi deneyimleri ve televizyon, onları bazen yanlış çıkarımlar yapacak şekilde yönlendirebilir. Bu noktada, anne-babanın devreye girmesi ve doğru olanı çocuğa açıklayarak göstermesi önemlidir.

Değinilen dört değişken grubu, çocukların ortaya koyacağı başarıyı ve hayat kalitesini \%100 oranında açıklamaya yetmez. Çünkü başarı ve hayat kalitesi, aile dinamiklerinden, arkadaş çevresinden, öğretmenden ve diğer çevresel faktörlerden de etkilenir. Ancak çocukların bu dört değişken grubuna ilişkin kazanımlar elde etmelerini sağlamak, onların kendileriyle ilişkili olan etkileri büyük ölçüde kontrol altında tutmalarına ve doğru tercihler yapmalarına yardımcı olacaktır.

\section{Çocuğumu Nasıl Desteklemeliyim?}

Bir çocuk, özel yetenekli olsun ya da olmasın, çevrenin etkisi ve desteğiyle gelişimini devam ettirir. Çevresel uyaranların zayıf olduğu bir ortamda, gelişim istenilen seviyede gerçekleşmeyecektir (Webb ve diğ., 2007). Bu yüzden aile her zaman çocuklarının hayatına dâhil olmalı ve çevreyi çocuğun yetenek, ilgi ve ihtiyaçları doğrultusunda yapılandırmalıdır. Aile müdahalesi, bazen çok aktif bir katılımı gerektirirken bazen de pasif kalmayı ama süreci denetlemeyi gerektirir.

Çocuk yetiştirirken tutarlı, açıklayıcı, anlaşılır ve sevgi dolu olmak gerekir. Çocuklara karşı gösterilen sevgi ve verilen değer, herhangi bir şarta bağlı olmamalıdır (Schunk, 2012). Aksi durumda, çocuk değerli olduğunu hissetmek ve saygı görmek için davranışlarında tutarsızlıklar gösterir. Ayrıca bu şart, başarı durumuysa en ufak bir başarısızlık, çocuğun kendini değersiz hissetmesine neden olacaktır (Schunk, 2012).

Maslow'un (1943) ortaya attığı ihtiyaçlar hiyerarşisi dikkate alındığında, ailelerin çocuklarını destekleme sürecindeki görevleri daha belirgin hale gelir. Çocuğu desteklemenin en nihai amacı, çocuğun kendini gerçekleştirmesini sağlamaktır (Maslow, 1943; Schunk, 2012). Kendini gerçekleştirmeden kastedilen durum, çocuğun yetenekli olduğu alanlarda ve ilgileri doğrultusunda hareket ederek hayattaki misyonunu tamamlamasıdır (Maslow, 1943). Çocuğun kendini gerçekleştirebilmesi için ilk olarak yemek, su gibi fizyolojik, emniyette hissetme gibi güvenlik ve sevgi, yakınlık gibi aidiyet ihtiyaçlarının anne-baba tarafından karşılanması gerekir (Maslow, 1943). Bu ihtiyaçlardan sonra öz saygı kazanma ve başkalarından saygı 
görme ihtiyacı gelir. Bu ihtiyacın karşılanmasıyla birlikte, çocuk son basamağa gelebilecek ve gerekli olgunluğa erişince kendini gerçekleştirmeye yönelik adımlar atmak için motive olabilecektir (Maslow, 1943).

Okul öncesi dönemde, özel yetenekli çocukların öz saygı ihtiyacını karşılamak ve sağlıkı bir benlik kavramı oluşturmalarını sağlamak için çocukların kendilerini tanımalarına ve yeteneklerini fark etmelerine olanak vermek, yetenekli oldukları alanlardaki gelişimlerini desteklemek için imkânlar sunmak ve böylece öz yeterlilik aşılamak oldukça önemlidir (Schunk, 2012). Öz saygı kazanmak için öz yeterliliğin de kazanılması gerekir. Öz yeterlilik aşılayarak öz saygı kazanmayı sağlamanın en ideal yollarından biri de çocuklara farklı etkinlik seçenekleri sunmak, yeteneklerine uygun olanlardan kendilerini mutlu hissettikleri seçenekleri yapmalarına imkân vermek ve bu etkinlikleri yaparken var olan potansiyellerini en ileri seviyeye taşımaları için onları cesaretlendirmektir (Schunk, 2012).

Etkinlikten kastedilen durumlar, çocukların evde ve parkta oynadıkları günlük oyunlar değil, çocuğun belirli periyotlarla sistematik olarak öğretmen, koç, antrenör veya ebeveyn gibi bir yetişkin gözetiminde yaptıklarıdır. Elbette çocuğun annesi ve babasıyla birlikte geçirdiği vakit, onun gelişimi için çok önemlidir ve ebeveynler bu vakitleri de mümkün olduğunca bilinçli bir şekilde geçirmeye önem vermelidir. Ancak, bir yeteneğin desteklenmesi ve en iyi şekilde geliştirilmesi için sistematik, planlı ve nitelikli bir sürecin devam ettirilmesi gerekir.

\section{Etkinlik Seçenekleri Sunmak}

Çocuğa farklı türde etkinlik seçeneklerinin sunulması ve buna ailenin öncülük etmesi gerekir (Schunk, 2012). Çünkü küçük çocuklar, farklı seçeneklerin varlığından haberdar değillerdir ve gelişimleri için etkinliklerin önemini henüz kavrayamamışlardır. Seçeneklerin sunulmasında, ailenin çocuğun yeteneğiyle alakalı gözlemleri kadar çocuğun ne tür etkinlikler yapmak istediği de önemlidir (Schunk, 2012). Ailenin yapmış olduğu gözlemler, çocuklarının yetenekli oldukları alanları ve ilgi alanlarını az çok bilmelerini sağlar. Dolayısıyla aile, kendi gözlemlerine dayanarak çocuğun yetenekleri ve ilgileri doğrultusunda etkinlikler sunabilir. Etkinlik belirlenmesi sürecinde, çocuğun fikrinin alınması da önemlidir. Küçük çocuklar, ebeveynlerinin fark ettiği ölçüde yeteneklerinin farkında olmasalar da çocukların etkinlik türlerine yönelik tercihleri, mutlu olacaklarını düşündükleri etkinlikleri yansıtır. Bu yüzden aileler, çocuktan gelen dönütleri ve kendi gözlemlerini dikkate alarak hem çocuğun yeteneğiyle 
örtüşen hem de çocuğun yapmaktan keyif aldığı etkinlikleri tercih etmeye önem vermelidir. Etkinlikler, bilişsel, spor, resim, müzik, akademik vb. alanlara ilişkin olabilir. Önemli olan, etkinliğin çocuğun yetenek ve ilgileriyle örtüşmesidir (Schunk, 2012).

Çocuğa bir etkinlik seçeneği sunulduğunda çocuk bu konuda istekli görünmezse bunun farklı gerekçeleri olabilir. Örneğin, çocuk başka bir etkinlik yapmak istiyor, sunulan etkinlik ilgisini çekmiyor veya sunulan etkinlikten korkuyor olabilir. Böyle bir durumda, gerçek nedenin ne olduğu çocukla konuşularak öğrenilmelidir. Var olan sebebe göre aile farklı yollarla çocuğun etkinliğe dâhil olmasını sağlayabilir ya da çocuğu uygun olan başka bir etkinliğe yönlendirebilir.

Çocuklar bir etkinliğe dâhil olmadan, o etkinlikten keyif alıp almayacaklarını tam olarak bilemezler. Bu sebeple eğer çocuğun bir etkinliğe karşı istekli olmama nedeni, etkinliğe ilgi duymamasıysa ilk birkaç seans için çocuğu teşvik edici bazı ödüller sunarak, çocuğun bu etkinliğe karşı motive olması sağlanmaya çalışılabilir. Eğer çocuk ilk birkaç seansta bu etkinlikten keyif almazsa bu etkinliği bırakıp başka bir etkinliğe yönelmek en doğru tercih olacaktır (Ryan \& Deci, 2000). Ancak çocuk, ilk birkaç seansta keyif aldığını ve mutlu olduğunu aileye yansıtırsa aile bu etkinliği devam ettirmesi için çocuğu desteklemeye devam etmelidir. Bu noktada, ödüllerle çocuğu motive etmekten vazgeçilmelidir. Böylece etkinliği yapmanın çocuğu motive etmesine imkân verilmiş olunur.

\section{Ebeveyn Beklentileri ve Çocuğun Yetenekleri}

Değinilmesi gereken ikinci nokta, ailelerin çocuklarına karşı olan beklentileri ile çocuğun var olan yetenekleri ve ilgileri arasındaki uyumdur. Her aile, çocukları olacağını öğrendikleri andan itibaren çocuklarının geleceklerine ilişkin hayaller kurmaya ve beklentiler oluşturmaya başlarlar. $\mathrm{Bu}$ hayallerin ve beklentilerin etkisiyle de çocuklarını erken yaşlarda belirli alanlara yöneltmeye çalışırlar. Çocuğun yetenek ve ilgileri ailenin beklentileriyle uyuşursa hem çocuk hem de aile memnuniyet duyacakları bir süreç yaşarlar. Ancak çocuğun yetenek ve ilgileri ailenin beklentileriyle uyuşmazsa ve aile çocuğun yeteneklerini ve ilgilerini göz ardı ederse çocuk için istenmeyen bir süreç karşımıza çıkar. Böyle bir durum, ne yazık ki hem çocuğu mutsuzlaştırır hem sunulan etkinlikten soğumasına sebep olur hem öz yeterlilik kaybını tetikler hem de aileyi olumsuz yönde etkileyen davranışların ortaya çıkmasına neden olur. Nihayetinde de çocuk, öğrenilmiş çaresizlik yaşamaya başlar ve kendini gerçekleştirme imkânı bulamaz (Pintrich, 2003). Bu nedenle çocuğun yetenekli olduğu alanların 
ilgileriyle harmanlanması oldukça önemlidir (Ryan \& Deci, 2000). Böylece çocuk, süreçten zevk almaya başlayacak, sürece istek duyarak dâhil olacak ve daha nitelikli bir süreç geçirerek başarılı olma olasılığını da artıracaktır (Schiefele, 1991).

Aileler, çocuklarının yetenek ve ilgileri doğrultusunda beklentilerini revize edebilmeli ve çocuklarını yetenekli oldukları alanlarda desteklemeyi öncelik olarak görmelidirler. İlgilerin ve ilgi alanlarında çocuğu desteklemenin, başarı üzerinde pozitif etkisinin olduğu unutulmamalıdır (Lee \& Shute, 2010; Schunk, 2012). Ayrıca, çocuk yetenekli olduğu alanda efor sarf ettikçe başarısını daha ileriye taşıyacak ve yakaladığı bu başarı, seviyesine uygun hedefler belirlemesinin yanında onun öz yeterlilik, öz güven ve öz saygı kazanmasına yardımcı olacaktır (Schunk, 2012; Pintrich, 2003).

\section{Ebeveyn-Çocuk Etkileşimi ve İletişimi}

Çocuk, alanında uzman bir kişiyle çalışmaya başladığında, "Zaten hocamız çocukla iyi bir şekilde ilgileniyor. Soru sorarak çocuğu daha fazla sıkboğaz etmeyelim." gibi bir yaklaşım, tavsiye edilen bir yaklaşım değildir (Schunk, 2012). Ebeveynler, çalıştıkları ve işleriyle alakalı var olan sorunlarla baş etmeleri gerektiği için zaman zaman çocuklarının yaptıkları etkinliklere dâhil olamayabilirler. Ancak bu durum, çocukların etkinliklere karşı motivasyon kaybı yaşamasına neden olabilmektedir (Ratelle, Guay, Larose, \& Senécal, 2004). Ailelerin sürece etkin şekilde dâhil olmamaları, çocukların kendilerini ve etkinliği değersizmiş gibi görmelerine, performanslarının düşmesine ve bir takım davranış sorunlarının ortaya çıkmasına sebebiyet verebilmektedir. Bu sebeple çocuğun çalışma süreci devam ederken, aileler sık sık çocukla iletişim kurmalı, çocuğa açıkça belli ederek yaptığıyla ilgilenmeli, sarf ettiği çaba için çocuğu takdir etmeli ve bu çabasından dolayı gurur duyduğunu ona söylemelidir. Çocukların, cesaretlendirici geri bildirim almaları, onların yaptıklarında istikrarlı olmalarını ve seviyelerini ileriye taşımalarını sağlayacaktır (Elliot \& Dweck, 1988).

Çocukların başarılarına ortak olmak da oldukça önemlidir. Çocuğun gelişimini ve öz saygısını desteklemek için önemli mihenk taşları olan başarılar beraberce kutlanarak çocuk ödüllendirilebilir. Çocuğun ortaya koyduğu başarı, onun için bir ödül olacaktır. Ancak bu başarıyı aile olarak beraberce kutlamak, çocuğun hem motivasyonunu ve mutluluğunu artıracak hem de yaptıklarına anne-babası tarafından değer verildiğini hissetmesini sağlayarak öz saygısını artıracaktır. Ayrıca bu kutlama, çocuk ve aile arasındaki bağı kuvvetlendirecek ve çocuğun duygusal gelişimine olumlu katkı yapacaktır. 
Bu kutlama süreci, çocukla beraber planlanmalı ve süreç için onun görüşleri öncelenmelidir. Anne-babalar, kutlama sürecine bir sürpriz dâhil etmeyi de düşünebilir. Ancak süreçteki kazanımların verdiği hazzı gölgelememek ve motivasyonu ödüle endekslememek adına, dâhil edilen bu sürprizde çok aşırıya kaçılmamalıdır. Yapılan kutlama ve sürprizin çocuğun öz yeterliliğine olumlu katkı sağlaması ve içsel motivasyonunu devam ettirmesine yardımcı olması için ailenin, çocuğun ortaya koyduğu performansa, harcadığı efora ve kaydettiği ilerlemeye vurgu yapması önemlidir (Schunk, 2012).

\section{Hedef Belirleme ve Geri Bildirim Verme}

Literatürde, iki tür hedeften bahsedilmektedir: öğrenme hedefleri ve performans hedefleri (Schunk, 2012). Öğrenme hedefleri, bilginin edinilmesinin, becerilerin kazanılmasının ve stratejilerin geliştirilmesinin önemsendiği hedeflerdir (Schunk, 2012). Diğer yandan performans hedefleri, süreçten ve süreçte elde edilecek kazanımlardan ziyade ulaşılacak olan sonucun önemsendiği hedefleri içerir (Schunk, 2012).

Öğrenme hedefleri, süreçteki kazanımları ön plana çıkardığı için çocuğun dikkatini yaptığı iş boyunca devam ettirmesini ve bilgi, beceri ve stratejileri daha nitelikli bir şekilde edinmesini sağlar (Schunk, 2012). Öğrenme hedeflerinin bir diğer olumlu yanı, çocuğu başkalarıyla değil de kendisiyle karşılaştırmaya imkân vermesidir (Pintrich, 2003). Öğrenme hedefleri doğrultusunda devam ettirilen bir süreç, çocuğun göstermiş olduğu gelişimin çocuk tarafından da fark edilmesine yardımcı olur. Çocuğun kendi gelişimini görmesi, öz yeterliliğinin yükselmesine ve öz güveninin artmasına katkı sağlar (Schunk, 2012; Pintrich, 2003).

Performans hedefleri, süreçteki kazanımlardan ziyade elde edilecek olan sonucu ön plana koyduğu için çocuğu, kendisiyle değil de başkalarıyla kıyaslamaya neden olur. Eğer çocuğun ortaya koyduğu ürün, diğerlerinin ortaya koyduklarından daha iyi bir ürünse bu durum çocuğun öz yeterliliğinin artmasına yardımcı olabilir (Schunk, 2012). Ancak bunun iki olumsuz yanı vardır. Birincisi, elde ettiği sonucu gereğinden fazla önemseyen bir çocuk, bu sonuca ulaşmasını sağlayan beceri ve stratejilerin önemini göz ardı edebilir (Schunk, 2012). İkinci olumsuz yan, öz yeterlilikle alakalıdır. Bir çocuğun, her alanda ve sürekli olarak en iyi ürünü ortaya koyması veya kazanması mümkün olmayacaktır. Çocuk, performans hedefleri belirleyip elde ettiği sonuca aşırı önem verdiğinde ve kendisinden daha nitelikli bir ürün ortaya koyan başka bir çocuk ortaya çıktığında, bu durum çocuğun öz yeterliliğinde bir düşüş yaşamasına sebep olacaktır (Schunk, 2012; Pintrich, 2003). 
Performans hedefleri tamamen göz ardı edilmemelidir. Hem öğrenme hem de performans hedeflerinin ideal bir oranda, doğru zamanlarda ve doğru yönlendirmelerle kullanılması başarıyı ve öz yeterliliği daha çok artıracaktır (Pintrich, 2003). Çünkü öğrenme hedefleri, öz yeterliliğin artmasına ve öz düzenlemenin sağlanmasına daha çok katkı yaparken (Schunk \& Swartz, 1993) performans hedefleri, sonuca ulaşması konusunda çocuğun motivasyonunu devam ettirmesini sağlayacaktır (Elliott \& Dweck, 1988; Stipek \& Kowalski, 1989).

Öğrenme hedefleri belirlemek ve bu hedeflere ulaşmak için çocuğun içsel bir motivasyona sahip olması önemlidir (Schunk, 2012). İçsel motivasyonu kazandırmanın ve devam ettirmenin en kolay yollarından biri de çocuğun yeteneği, seviyesi ve ilgi alanlarıyla uyuşan etkinlik seçeneklerini çocuğa sunmaktır (Ryan \& Deci; Lepper \& Hodell, 1989). Bu sayede çocuk, etkinliğe dâhil olmaktan keyif alacak, süreçte elde ettiği kazanımları önceleyecek ve etkinlik sürecinde yaptıklarıyla motive olabilecektir.

Öğrenme hedefleri belirlenmiş ve içsel bir motivasyon kazanılmış bir şekilde süreç devam ettirilirken sürece ödül bileşeninin dahil edilmesinde çok dikkatli olunmalıdır. Eğer bir ödül verilecekse bu ödülün ne zaman verildiği önemlidir. Çünkü süreç sonlanmadan verilen bir ödül, içsel motivasyonu olumsuz yönde etkileyecek ve çocuğun motivasyonunu dişsal bir kaynağa kaydıracaktır (Deci, Koestner, \& Ryan, 2001; Lepper, Corpus, \& Iyengar, 2005). Bu dışsal motivasyon kaynağının devamı gelmediğinde de çocuk bu etkinliği devam ettirme isteği duymayacaktır. Ayrıca böyle bir yaklaşım, çocuğun dışsal motivasyon kaynaklarına daha fazla önem vermesini de tetikleyecektir. Bu sebeple, verilecek ödüllerin süreç sonlandıktan sonra verilmesi ve ödülün, elde edilen sonuçla değil de süreçte harcanan efor ve elde edilen kazanımlarla ilişkilendirilmesi önemlidir (Schunk, 1983). Ödülün çocuğun göstermiş olduğu çaba ve ilerleme sebebiyle verildiğini söylemek de çocuğun öğrenme hedeflerinin önemini anlamasına ve öğrenme hedefleri belirleyebilmesine yardımcı olacaktır (Schunk, 2012).

Süreç esnasında ve süreç sonlandıktan sonra çocuklara verilecek olan geri bildirimlerde de dikkat edilmesi gereken noktalar vardır. Geri bildirim verirken dikkate alınması gereken en önemli hususlardan biri, geri bildirimin ne kadar güvenilir, samimi ve inandırıcı olduğudur (Schunk, 2012). Süreç devam ederken verilen geri bildirim, çocuğun belirlediği hedefi gerçekleştirebileceğine ilişkin onu ikna etmeli ve çocuğun yapabilecekleriyle uyumlu olmalıdır.

Çocukların, yeteneklerine vurgu yapan cesaretlendirici geri bildirim almaları, onların yaptıklarında istikrarlı olmalarını ve seviyelerini ileriye 
taşımalarını sağlar. Elliot ve Dweck (1988), öğrenme hedefleri belirleyen çocuklara yeteneklerine vurgu yaparak geri bildirim verdiklerinde, çocukların hem süreci istikrarlı şekilde sürdürdüklerini hem de kendilerini zorlayıcı seçenekleri seçtiklerini bulmuşlardır. Aynı çalışmada, performans hedefi belirleyen çocuklar, yeteneklerine vurgu yapıldığında süreci istikrarlı şekilde devam ettirmiş olsalar da kendilerini zorlayıcı seçenekleri tercih etmemişlerdir. Performans hedefi belirleyen ve geri bildirim almayan çocuklar ise hem süreci sürdürmekte sorun yaşamışlar hem de kendilerini zorlayıcı tercihler yapmamışlardır.

Bazen çocuklar zorlandıklarını hissederler. Bu noktada, çocuğun çalıştığı kişilerin çocuğun yeteneklerinin yanında önceden ortaya koymuş olduğu başarıları da çocuğa hatırlatmaları önemlidir (Schunk, 2012). Bu tür bir geri bildirim, çocuğun üzerinde çalıştığı görevi tamamlayabileceğine ilişkin inancını pekiştirecek ve kendine güven duymasına yardımcı olacaktır (Schunk, 2012). Bu da çocuğun süreci devam ettirmesine imkân verecek ve başarısını daha ileriye taşımasına katkı sağlayacaktır.

\section{Kimdir Bu İki Kere Farklı Çocuklar?}

Birçok özel yetenekli çocuk, var olan yetenekleri sayesinde başarılı ve çok ciddi sorunlar yaşamadıkları bir hayat devam ettirmektedir. Ancak bazı özel yetenekli çocuklarda, bir yetersizliğin sebep olduğu ikinci bir özel gereksinim durumu bulunmaktadır. Bu gereksinim durumu, işitme kaybı, görme kaybı, hareket kaybı, öğrenme güçlüğü, otizm, konuşma bozukluğu, duygu ve davranış bozukluğu, dikkat eksikliği ve hiperaktivite bozukluğu veya kronik bir hastalık olabilmektedir (Trail, 2011). Bu çocuklar, hem yüksek yeterlilik sonucu özel yetenekli olduğu hem de yetersizlik sonucu engeller yaşadığı yani birbiriyle tezat iki duruma sahip olduğu için iki kere farklı olan çocuklar olarak karşımıza çıkmaktadır (Yörük, 2020).

\section{Gereksinimlerin Fark edilmesi}

Bir çocuğun özel yetenek potansiyeli ve yetersizlik sonucu yaşadığı engeller, farklı zamanlarda ortaya çıkmaktadır. Hangisinin önce fark edileceği, yetersizliğin ve özel yeteneğin türüne göre değişmektedir. Kaza veya hastalık gibi bir neden sonucu değil de genetik yapının etkisiyle ortaya çıkan yetersizliklerde, çocuğun yaşadığı engeller, çoğu zaman özel yetenek potansiyelinin fark edilmesinden daha önce dikkat çekmektedir. 2020/2 Örneğin, işitme, görme ve hareket kaybı doğumun hemen sonrasında fark edilmektedir. Otizm spektrum bozukluğu 1-2 yaşlarında fark edilmeye 
başlanmaktadır (Sönmez-Kartal, 2017). Engellerin fark edilmesi, sonraki yaşlara da sarkabilmektedir. Örneğin, dil ve dikkat becerilerini etkileyen öğrenme güçlüğü, çocuk alıcı ve ifade edici dil becerilerini aktif şekilde kullanmaya başladığında gözlemlenebilmektedir (Melekoğlu, 2018). Okuma, yazma ve matematik becerilerini etkileyen öğrenme güçlüğünün ve diğer özel gereksinim durumlarının fark edilmesi ve tanılanması ise ilerleyen yaşlara sarkabilmektedir.

Özel yetenek, erken gelişimle direkt ilişkili olan bir durum olduğu için çocuğunun gelişim sürecini dikkatlice takip eden ve bu gelişim sürecini normal gelişim gösteren çocuklarla kıyaslayan aileler, 1 yaşlarından itibaren bir özel yetenek potansiyelini, özellikle IQ alanındaki bir potansiyeli sezebilirler. Çocuğun alıcı ve ifade edici dil becerilerini kullanmaya başladığı dönemde, IQ alanındaki özel yetenek potansiyeli kendini daha belirgin şekilde göstermeye başlar. Diğer alanlardaki özel yetenek potansiyeli ise ilerleyen yaşlara doğru daha belirgin hale gelir.

Bazen, yetersizlik durumu özel yeteneğin önüne geçebilir veya her iki durum birbirini maskeleyebilir (Yörük, 2020). Her iki olasılık da özel yeteneğin fark edilmemesiyle sonuçlanabilir. Birinci olasılıkta, çocuk, yaşadığı engellere ilişkin tanı alır ama özel yeteneği göz ardı edilir. İkinci olasılıkta, çocuk, ne özel yeteneği ne de yaşadığı engeller için tanı alır. İkinci olasılık, özellikle öğrenme güçlüğü yaşayan özel yetenekli çocuklarda karşımıza çıkmaktadır (Yörük, 2020).

Herhangi bir yetersizlik görülen bir çocuğa sahip hiçbir ebeveyn, çocuklarının özel yetenekli olabileceğini unutmamalıdır. Yetersizlik durumlarında, özel yeteneğin ortaya çıkma ihtimali belirli oranda azalsa da sayısı azımsanamayacak miktardaki çocuk iki kere farklıdır. Bunun tam tersi de geçerlidir. Özel yetenek tanısı almış bir çocuk, var olan bir yetersizlik sebebiyle özel eğitim kapsamına giren başka bir gereksinime sahip olabilir. Bir alanda yüksek performans ortaya koyan ama aynı zamanda bir yetersizlik görülen kişiler bunun en belirgin örnekleridir (bkz. Metin Şentürk, Ray Charles, Stephen Wiltshire, Michael Phelps ve Stephen Hawking).

\section{İki Kere Farklı Çocukların Gereksinimleri}

İki kere farklı çocuklar, özel yeteneğin ve diğer özel gereksinim durumunun bir arada görülmesi sonucu, her iki gruptan farklı bir tip gereksinime sahip olmazlar (Yörük, 2020). Bu çocukların, hem özel yeteneklerinden dolayı 2020/2 ortaya çıkan ihtiyaçları hem de yetersizlik sonucu ortaya çıkan ihtiyaçları vardır. İki kere farklı çocuklara sahip olan aileler ve bu çocuklarla çalışan 
profesyoneller, bu çocukların hem özel yetenekten hem de yetersizlikten dolayı ortaya çıkan ihtiyaçlarını dikkate almalıdırlar. Bu ihtiyaçların karşılanmasına yönelik süreç ayrı ayrı planlanabilir ama bu planların uygulanması sürecinde, çocuğun hem özel yetenekli hem de başka bir özel gereksiniminin olduğu unutulmamalıdır (Yörük, 2020).

\section{Sonuç}

Birçok aile, sırf 'özel yetenek’ etiketi sebebiyle özel yetenekli çocukların, yaşıtlarından daha "üstün” olduğu yanılgısına kapılarak çocuklarına karşı gerçek dışı beklentiler oluşturmakta ve çocuklarının gelişimini nasıl destekleyeceklerini tam olarak bilememektedirler. Özel yetenekli çocukların sağlıklı, mutlu ve başarılı bir hayat geçirmeleri, bu çocuklarla alakalı doğru bir bakış açısına sahip olunmasıyla mümkün olur. Bu çalışmada, özel yetenekli çocuklarla alakalı ailelerin bilmesi gereken altı önemli soru üzerinde durulmuştur. Bu altı sorunun cevaplarındaki en önemli noktalar kısaca şöyle özetlenebilir:

-IQ akademik başarı üzerindeki etkisinden dolayı hâlâ çok önemli bir kavram olsa da özel yetenekliler grubu sadece çok yüksek IQ sahibi olan çocuklardan meydana gelmez. Bir çocuk, IQ alanında özel yetenekli olabileceği gibi ortalama üstü bir zihinsel gelişim seviyesinde bulunup yaratıcı düşünme, liderlik, sanat, psikomotor ve akademik alanların birinde veya birkaçında da özel yetenekli olabilir.

-Özel yetenekli çocuklar, özel yetenekli oldukları alanlarda yaşıtlarının ilerisinde bir gelişim seviyesine sahip olurlar. Bu sayede, o alandaki bilgi ve beceriyi yaşıtlarından daha hızlı, erken ve fazla olacak şekilde edinirler ve daha etkili olacak şekilde kullanırlar.

-Özel yetenekli çocukların tanılanması için sadece IQ testleri kullanılmamalıdır. Farklı yetenek alanlarına ait güvenilir ve geçerli sonuçlar veren değerlendirme araç ve yöntemleri, IQ dışındaki alanlarda özel yetenekli olan çocukları tanılamak için kullanılabilir.

-Özel yetenekli çocuklar, yetenekli oldukları alanlardaki bilgi ve beceriyi yaşıtlarından erken öğrenebildikleri için belirli bilgi ve becerilerle yaşıtlarından erken tanıştırılabilirler. Ancak bilgi ve becerilerin yanında, benlik kavramının, öz düzenlemenin ve erdem davranışlarının kazandırılması da başarılı ve mutlu bir hayat için önemlidir.

-Özel yetenekli çocuklara, kendilerini tanımaları ve yeteneklerini keşfedip ilgi alanlarında kendilerini gerçekleştirmeleri için etkinlik seçeneklerinin 
sunulması önemlidir. Seçenekler arasından, çocuğun ilgi ve yetenekleriyle örtüşenleri yapması konusunda çocuk desteklenmelidir.

-Bazı özel yetenekli çocuklarda, yetersizlik sonucu ortaya çıkan ikinci bir özel gereksinim durumu olabilir. Bu çocuklar, yaşadıkları engellerle daha çok dikkat çektikleri için yeteneklerinin fark edilmemesi ve sonucunda da ihtiyaçlarının göz ardı edilmesi riskiyle karşı karşıyadırlar. Zihin yetersizliği hariç, herhangi bir yetersizlik görülen çocukların bazıları aynı zamanda özel yetenekli olabilir. Bu yüzden aileler, çocuklarında işitme kaybı, görme kaybı, hareket kaybı, öğrenme güçlüğü, otizm, konuşma bozukluğu, duygu ve davranış bozukluğu, dikkat eksikliği ve hiperaktivite bozukluğu veya kronik bir hastalık olsa bile çocuklarını gözlemlemeye devam etmelidir.

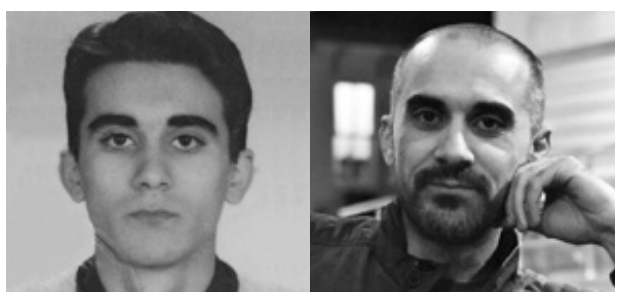

Süreyya Yörük

\section{Kaynakça}

Anderson, L. W. \& Krathwohl, D. R. (2001). A taxonomy for learning, teaching, and assessing: A revision of Bloom's taxonomy of educational objectives. New York: Longman.

Bandura, A. (1986). Social foundations of thought and action: A social cognitive theory. Englewood Cliffs, NJ: Prentice-Hall.

Bandura, A. (1997). Self-efficacy: The exercise of control. New York: Freeman.

Bandura, A. \& Cervone, D. (1983). Self-evaluative and self-efficacy mechanisms governing the motivational effects of goal systems. Journal of Personality and Social Psychology, 45, 1017-1028.

Bertua, C., Anderson, N., \& Salgado, J. F. (2005). The predictive validity of cognitive ability tests: A UK meta-analysis. Journal of Occupational and Organizational Psychology, 78, 387-409.

Bloom, B. S., Engelhart, M. D., Furst, E. J., Hill, W. H., \& Krathwohl, D. R. (1956). The taxonomy of educational objectives, handbook I: The cognitive domain. New York: David McKay.

Comte-Sponville, A. (2020). Büyük erdemler risalesi. İstanbul: İletișim.

Cross, T. L. (2018). On the social and emotional lives of gifted children. Waco, TX: Prufrock.

Deci, E. L., Koestner, R., \& Ryan, R. M. (2001). Extrinsic rewards and intrinsic motivation in education: Reconsidered once again. Review of Educational Research, 71, 1-27.

Elliott, E. S. \& Dweck, C. S. (1988). Goals: An approach to motivation and achievement. Journal of Personality and Social Psychology, 54, 5-12.

Gagné, F. (2004). Transforming gifts into talents: The DMGT as a developmental theory. High Ability Studies, 15, 119-147.

Gardner, H. (1983). Frames of mind: The theory of multiple intelligences. New York, NY: Basic Books. Shavinina (Edt.) International Handbook on Giftedness (s. 261-273). Springer.

Guilford, J. P. (1959). Three faces of intellect. American Psychologist, 14, 469-479. 
Hattie, J. (2009). Visible learning: A synthesis of over 800 meta-analyses related to achievement. London: Routledge, Taylor and Francis Group.

Jolly, J. L. (2005). Pioneering definitions and theoretical positions in the field of gifted education. Gifted Child Today, 28(3), 38-44.

Kern, M. L. \& Friedman, H. S. (2008). Early educational milestones as predictors of lifelong academic achievement, midlife adjustment, and longevity. Journal of applied developmental psychology, 30, 419-430.

Lee, J. \& Shute, V. J. (2010). Personal and social-contextual factors in K-12 academic performance: An integrative perspective on student learning. Educational Psychologist, 45, 185-202.

Lee, J. \& Stankov, L. (2018). Non-cognitive predictors of academic achievement: Evidence from TIMSS and PISA. Learning and Individual Differences, 65, 50-64.

Lepper, M. R. \& Hodell, M. (1989). Intrinsic motivation in the classroom. C. Ames \& R. Ames (Edt.), Research on motivation in education Vol. 3 (s. 73-105). San Diego: Academic Press.

Lepper, M. R., Corpus, J. H., \& Iyengar, S. S. (2005). Intrinsic and extrinsic motivational orientations in the classroom: Age differences and academic correlates. Journal of Educational Psychology, 97 , 184-196.

Mackintosh, N. J. (2011). Intelligence and its measurement: 1. History of theories and measurement of intelligence. R. J. Sternberg \& S. B. Kaufman (Edt.), The Cambridge handbook of intelligence (s. 1-19). Cambridge: Cambridge University.

Marland, S. P., Jr. (1972). Education of the gifted and talented: Report to the congress of the United States by the U.S. commissioner of education and background papers submitted to the U.S. office of education, 2 vols. Washington, DC: U.S. Government Printing Office. (Government Documents Y4.L 11/2: G36).

Maslow, A. H. (1943). A theory of human motivation. Psychological Review, 50, 370-396.

Melekoḡlu, M. A. (2018). Özel öḡrenme güçlüḡüne giriș. M. A. Melekoḡlu \& O. Çakıroḡlu (Ed.), Özel ögrenme güçlüğü olan çocuklar (s. 1-33). Ankara: Vize Akademik.

Milli Eḡitim Bakanlığı. (2018). Özel ēgitim hizmetleri yönetmeliḡi. Resmî Gazete, 30471, 22-77.

Moon, T. R. (2012). Performance assessment: The role in the identification of gifted students. S. L. Hunsaker (Edt.), Identification: The theory and practice of identifying students for gifted and talented education services (s. 381-389). Waco, TX: Profrock.

Mowlaie, M., Besharat, M. A., Pourbohlool, S., \& Azizi, L. (2011). The mediation effects of selfconfidence and sport self-efficacy on the relationship between dimensions of anger and anger control with sport performance. Procedia-Social and Behavioral Sciences, 30, 138-142.

Piaget, J. (1971). The theory of stages in cognitive development. In D. R. Green, M. P. Ford, \& G. B. Flamer, Measurement and Piaget. McGraw-Hill.

Pintrich, P. R. (1999). The role of motivation in promoting and sustaining self-regulated learning. International Journal of Educational Research, 31, 459-470.

Pintrich, P. R. (2003). Motivation and classroom learning. W. M. Reynolds \& G. E. Miller (Edt.), Handbook of psychology: Educational psychology Vol. 7 (s. 103-122). John Wiley \& Sons.

Pintrich, P. R. \& Schrauben, B. (1992). Students' motivational beliefs and their cognitive engagement in classroom academic tasks. D. H. Schunk \& J. L. Meece (Edt.), Student perceptions in the classroom (s. 149-183). Hillsdale, NJ: Erlbaum.

Ratelle, C. F., Guay, F., Larose, S., \& Sen cal, C. (2004). Family correlates of trajectories of academic motivation during a school transition: A semiparametric group-based approach. Journal of Educational Psychology, 96, 743-754.

Renzulli, J. S. (1986). The three-ring conception of giftedness: A developmental model for creative productivity. R. J. Sternberg \& J. E. Davidson (Edt.), Conceptions of giftedness (s. 53-92). Cambridge, MA: Cambridge University.

Rhode, T. E. \& Thompson, L. A. (2007). Predicting academic achievement with cognitive ability. Intelligence, 35, 83-92.

\section{Okul Öncesi Dönemde Özel Yetenekli Bir Çocuk Yetiştirmek}


Richardson, M., Abraham, C., \& Bond, R. (2012). Psychological correlates of university students' academic performance: A systematic review and meta-analysis. Psychological Bulletin, 138, 353387.

Richardson, K. \& Norgate, S. H. (2015). Does IQ really predict job performance? Applied Developmental Science, 19, 153-169.

Richardson, M., Abraham, C., \& Bond, R. (2012). Psychological correlates of university students' academic performance: A systematic review and meta-analysis. Psychological Bulletin, 138(2), 353-387.

Rimm, S. B., Siegle, D., \& Davis, G. A. (2018). Education of the gifted and talented. New York, NY: Pearson.

Robinson, N. M. (1993). Parenting the very young, gifted child (RBDM9308). Storrs: University of Connecticut, The National Research Center on the Gifted and Talented.

Roid, G. H. \& Barram, R. A. (2004). Essentials of Stanford-Binet intelligence scales (SB5) assessment. Hoboken: Wiley.

Runco, M. A. \& Jaeger, G. J. (2012). The standard definition of creativity. Creativity Research Journal, 24, 92-96.

Ryan, R. M. \& Deci, E. L. (2000). Self-determination theory and the facilitation of intrinsic motivation, social development, and well-being. American Psychologist, 55, 68-78.

Schiefele, U. (1991). Interest, learning, and motivation. Educational Psychologist, 26, 299-323.

Schmidt, F. L., \& Hunter, J. E. (2003). History, development, evolution, and impact of validity generalization and meta-analysis methods. 1975-2001. K. R. Murphy (Edt.), Validity generalization: A critical review. Hove, England: Erlbaum.

Schunk, D. H. (1983). Reward contingencies and the development of children's skills and self-efficacy. Journal of Educational Psychology, 75, 511-518.

Schunk, D. H. (1995). Self-efficacy and education and instruction. J. E. Maddux (Edt.), Self-efficacy, adaptation, and adjustment: Theory, research, and applications (s. 281-303). New York, NY: Plenum.

Schunk, D. H. (2012). Learning theories: An educational perspective. London: Pearson.

Schunk, D. H. \& Swartz, C. W. (1993b). Writing strategy instruction with gifted students: Effects of goals and feedback on self-efficacy and skills. Roeper Review, 15, 225-230.

Shiner, R. L., Ann S. Masten, A. S., \& Roberts, J. M. (2003). Childhood personality foreshadows adult personality and life outcomes two decades later. Journal of Personality, 71, 1145-1170.

Sönmez-Kartal, M. (2017). Otizm spektrum bozukluḡu olan çocuklar. A. Arı \& M. Sönmez-Kartal (Ed.), Tüm öğretmenlik programları için özel eḡitime giriș (s. 131-149). Konya: Eğitim Yayınevi.

Sternberg, R. (2005). The WICS model of giftedness. R. Sternberg \& J. Davidson (Edt.), Conceptions of Giftedness (s. 327-342). Cambridge: Cambridge University.

Stipek, D. J. \& Kowalski, P. S. (1989). Learned helplessness in task-orienting versus performanceorienting testing conditions. Journal of Educational Psychology, 81, 384-391.

Torrance, E. P. (1979). The search for satori and creativity. Buffalo, NY: Creative Education Foundation.

Trail, B. A. (2011). Twice-exceptional gifted children: Understanding, teaching, and counseling gifted students. Waco, TX: Prufrock.

Van Tassel-Baska, J. \& Stambaugh, T. (2006). Comprehensive curriculum for gifted learners. Boston, MA: Allyn and Bacon.

Webb, J. T., Devries, A. R., Amend, E. R., \& Gore, J. L. (2007). A Parent's Guide to Gifted Children. Scottsdale, AZ: Great Potential.

364

Cocuk ve Medeniyet 2020/2
Yörük, S. (2020). Çoklu gereksinimi olan üstün zekalı ve yetenekliler. A. P. Konyalıoḡlu (Edt.), Üstün zekalı ve yetenekli çocuklar (s. 196-224). İstanbul: Açık ve Uzaktan Eğitim Fakültesi Yayınları.

Zimmerman, B. J. \& Ringle, J. (1981). Effects of model persistence and statements of confidence on children's self-efficacy and problem solving. Journal of Educational Psychology, 73, 485-493.

\section{Süreyya Yörük}

